\title{
Peningkatan Pertumbuhan Tanaman Cabai dan Pengendalian Busuk Phytophthora melalui Biopriming Benih dengan Rizobakteri Asal Pertanaman Cabai Jawa Timur
}

\author{
Improve Plant Growth of Chilli and Control Phytophthora Blight with Biopriming of \\ Seed Using Rhizobacteria from Chili Plants in East Java
}

\author{
Aulia Zakia ${ }^{1}$, Satriyas Ilyas ${ }^{2 *}$, Candra Budiman ${ }^{2}$, Syamsuddin $^{3}$, dan Dyah Manohara ${ }^{4}$
}

Diterima 07 November 2016/Disetujui 18 Oktober 2017

\begin{abstract}
The objectives of this study was to evaluate biopriming of chili seed with rhizobacteria to improve plant growth and control Phytophthora blight disease in a greenhouse. This experiment used three isolates of rhizobacteria, i.e. E1, E3C2 and F2B1, and isolate Phytophthora capsici (Cb6) isolated from the production center of chili in East Jawa. Laris variety from PT. East West was used in this experiment. This experiment used randomized block design with one factor, i.e. 11 levels of seed treatment (E1 rhizobacteria, E3C2 rhizobacteria, F2B1 rhizobacteria, E1+E3C2 rhizobacteria, E1 $+F 2 B 1$ rhizobacteria, E1 $+E 3 C 2+F 2 B 1$ rhizobacteria, seed soaking in water, without soaking, metalaxyl, positive control and negative control). The result showed that seed treatment with combination of E1+F2B1 isolates when grown in nursery, significantly increased the height and number of leaves in chilli. Besides, seed treatment with F2B1 isolate and combination of $E 1+F 2 B 1$ isolates after transplanting were capable to improve plant growth and control Phytophthora blight disease in greenhouse.
\end{abstract}

Keywords: greenhouse, isolate rhizobacteria, Phytophthora capsici

\begin{abstract}
ABSTRAK
Tujuan penelitian ini ialah mengevaluasi perlakuan biopriming benih cabai dengan rizobakteri dalam meningkatkan pertumbuhan bibit dan mengendalikan kejadian busuk Phytophthora di rumah kaca. Perlakuan biopriming benih dengan rizobakteri menggunakan tiga isolat rizobakteri E1, E3C2 dan F2B1 dan isolat Phytophthora capsici Cb6 hasil eksplorasi pertanaman cabai Jawa Timur. Benih yang digunakan dalam percobaan merupakan benih varietas Laris produksi PT. East West. Percobaan menggunakan rancangan acak kelompok satu faktor, masing-masing perlakuan diulang empat kali, dengan 11 taraf perlakuan, antara lain R0+ (kontrol positif, benih direndam dalam PDB tanpa perlakuan rizobakteri dengan inokulasi $P$. capsici), R0- (kontrol negatif, benih direndam dalam PDB tanpa perlakuan rizobakteri dan tanpa inokulasi $P$. capsici), R1 (perlakuan benih dengan isolat $\mathrm{E} 1$ ), R2 (isolat $\mathrm{E} 3 \mathrm{C} 2$ ), R3 (isolat $\mathrm{F} 2 \mathrm{~B} 1$ ), R4 (kombinasi isolat $\mathrm{E} 1+\mathrm{E} 3 \mathrm{C} 2$ ), R5 (kombinasi isolat $\mathrm{E} 1+\mathrm{F} 2 \mathrm{~B} 1$ ), R6 (kombinasi isolat $\mathrm{E} 1+\mathrm{E} 3 \mathrm{C} 2+\mathrm{F} 2 \mathrm{~B} 1$ ), R0RA (benih direndam dalam air 24 jam), R0TR (benih tanpa rendam), R0M (benih direndam dalam metalaksil). Tanah inokulum $P$. capsici diberikan 28 hari setelah pindah-tanam di sekitar pangkal batang tanaman cabai di bawah permukaan tanah. Hasil percobaan menunjukkan, perlakuan dengan kombinasi isolat E1+F2B1 saat persemaian di rumah kaca nyata meningkatkan tinggi dan jumlah daun tanaman cabai. Perlakuan benih dengan isolat F2B1 maupun kombinasi isolat $\mathrm{E} 1+\mathrm{F} 2 \mathrm{~B} 1$ setelah pindah-tanam di rumah kaca memiliki kemampuan meningkatkan pertumbuhan tanaman serta mengendalikan penyakit busuk Phytophthora.
\end{abstract}

Kata kunci: isolat rizobakteri, Phytophthora capsici, rumah kaca

\footnotetext{
${ }^{1}$ Mahasiswa Program Studi Ilmu dan Teknologi Benih, Sekolah Pascasarjana, Institut Pertanian Bogor

${ }^{2}$ Departemen Agronomi dan Hortikultura, Fakultas Pertanian, Institut Pertanian Bogor (Bogor Agricultural University), Jl. Meranti, Kampus IPB Darmaga, Bogor 16680, Indonesia

${ }^{3}$ Departemen Agroekoteknologi Fakultas Pertanian, Universitas Syah Kuala, Kampus Darussalam, Banda Aceh, Indonesia

${ }^{4}$ Balai Penelitian Tanaman Obat dan Aromatik, Jl. Tentara Pelajar No. 3A Menteng, Bogor Barat

Email: satriyas252@gmail.com (*penulis korespondensi)
} 


\section{PENDAHULUAN}

Invigorasi merupakan upaya memperbaiki mutu fisiologis benih dengan meningkatkan performa benih yang telah mengalami kemunduran (deteriorasi). Invigorasi benih sebelum tanam dapat dilakukan dengan mekanisme penyerapan air oleh benih secara terkontrol, yaitu dengan cara priming (osmopriming/ osmoconditioning) dan solid matrix priming/ matriconditioning (Ilyas, 2012). Perbedaan antara priming dengan matriconditioning adalah media yang digunakan. Priming menggunakan media cairan, sedangkan matriconditioning menggunakan media padat dalam keadaan lembab dengan potensial matrik rendah (daya ikat air yang tinggi) (Sutariati et al., 2014). Kedua media yang digunakan dalam perlakuan tersebut harus memiliki sifat tidak beracun bagi benih.

Priming dengan mengintegrasikan agens hayati dalam larutan perlakuan disebut biopriming (Ilyas et al., 2015). Biopriming menggunakan rizobakteri yang memiliki kemampuan sebagai biofertiliser atau PGPR, serta berperan menjadi antagonis dipilih sebagai perlakuan benih untuk mendapatkan hasil yang maksimal. Menurut Sutariati et al. (2014), selain memberikan perbaikan, perlakuan biopriming juga berperan sebagai media inokulasi rizobakteri terhadap benih. Invigorasi benih melalui biopriming dengan rizobakteri memberikan manfaat bagi tanaman, serta terbukti efektif meningkatkan viabilitas dan vigor benih (Ilyas et al., 2002; Sutariati et al., 2014).

Pengendalian penyakit busuk Phytophthora, yang disebabkan oleh cendawan Phytophthora capsici umumnya dilakukan dengan mengaplikasikan fungisida sintetik, bahan aktif metalaksil dan mefanoksam (Hausbeck dan Lamour, 2004). Pengendalian dengan cara tersebut menyebabkan adanya residu yang tertinggal dan merusak lingkungan. Cendawan P. capsici bersifat soil borne dan water borne (Wahyuno, 2009), serta seed borne (Agarwal dan Sinclair, 1997). Biopriming benih dengan menambah rizobakteri dapat menjadi alternatif perlakuan untuk mengendalikan penyakit busuk Phytophthora. Hasil penelitian Syamsuddin (2010), Ibrahim et al. (2014), dan Rosadiah et al. (2015), menunjukkan bahwa rizobakteri sebagai perlakuan benih mampu meningkatkan pertumbuhan tanaman dan mengendalikan penyakit busuk Phytophthora yang disebabkan oleh patogen $P$. capsici. Kemampuan rizobakteri sebagai agen biokontrol inilah yang secara tidak langsung dapat meningkatkan mutu kesehatan benih. Berdasarkan penjelasan tersebut, penelitian ini bertujuan mengevaluasi perlakuan biopriming benih dengan rizobakteri yang efektif meningkatkan pertumbuhan tanaman cabai dan mengendalikan penyakit busuk Phytophthora di rumah kaca.

\section{BAHAN DAN METODE}

Penelitian dilaksanakan di Laboratorium Hama dan Penyakit Balittro (Balai Penelitian Tanaman Rempah dan Obat) Cimanggu, Laboratorium Kesehatan Benih dan rumah kaca Leuwikopo, Departemen Agronomi dan Hortikultura, Fakultas Pertanian Institut Pertanian Bogor. Penelitian dimulai bulan Oktober 2015 sampai Februari 2016.

\section{Benih Cabai}

Percobaan menggunakan benih cabai varietas Laris yang diproduksi dan diperoleh dari PT. East West Indonesia. Benih cabai dipanen tanggal 19 November 2014. Benih disimpan selama 7 bulan dalam ruang simpan benih dengan suhu $20{ }^{0} \mathrm{C}$ (setelah benih didapatkan dari PT. East West Indonesia pada Maret 2015, sampai benih digunakan dalam percobaan). Benih cabai sebelum digunakan dalam percobaan terlebih dahulu diuji daya berkecambah, indeks vigor, keserempakan tumbuh (metode uji di atas kertas stensil, ISTA, 2014), dan kadar air (metode oven suhu rendah, ISTA, 2014). Hasil pengujian mutu benih pada 6 Oktober 2015 menunjukkan bahwa daya berkecambah sebesar $64 \%$, indeks vigor $0 \%$, keserempakan tumbuh $10.8 \%$, dan kadar air 5.5\%. Indeks vigor nol, disebabkan oleh kadar air benih rendah saat pengujian, sehingga membutuhkan waktu yang relatif lama dalam periode imbibisi benih, ditunjukkan dengan tidak ada kecambah normal pada hitungan pertama (7 hari setelah tanam). Benih cabai varietas Laris dipilih karena menurut Yunianti et al. (2007), rentan terhadap serangan $P$. capsici. 
Tabel 1. Tiga isolat rizobakteri terpilih dan memiliki kemampuan untuk menghambat $P$. capsici

\begin{tabular}{cllc}
\hline Sampel & \multicolumn{1}{c}{ Keterangan } & Asal Isolat & Media Isolasi \\
\hline E1 & $\begin{array}{l}\text { Berasal dari lokasi E (Desa Tegalgondo, Kec. } \\
\text { Dau, Kab. Malang, Jawa Timur) } \\
\text { (kode isolat Eana3) }\end{array}$ & Rizoplan \\
E3C2 & $\begin{array}{l}\text { Berasal dari lokasi E (Desa Tegalgondo, Kec. } \\
\text { Dau, Kab. Malang, Jawa Timur) } \\
\text { (kode isolat Eatsap1) }\end{array}$ & Rizoplan & TSAP \\
F2B1 & $\begin{array}{l}\text { Berasal dari lokasi F (Desa Gayam, Kec. } \\
\text { Gurah, Kab. Kediri, Jawa Timur) } \\
\text { (kode isolat Fana9) }\end{array}$ & Rizoplan & NA \\
\hline Keterangan: & $\begin{array}{l}\text { rizoplan = rizosfer yang menempel pada perakaran tanaman; NA = media isolasi rizobakteri natrium } \\
\text { agar; TSAP = media isolasi rizobakteri tryptic soy agar } \text { (TSA), yang dimodifikasi dengan memanaskan } \\
\text { suspensi tanah rizosfer dalam waterbath pada suhu 80 }{ }^{\circ} \mathrm{C} \text { selama 30 menit sebelum digunakan dalam } \\
\text { isolasi rizobakteri. }\end{array}$
\end{tabular}

\section{Isolat Rizobakteri dan Phytophthora capsici}

Tiga isolat rizobakteri yang digunakan merupakan isolat yang memiliki daya hambat tertinggi hasil penelitian (in vitro) sebelumnya, diperoleh dari hasil eksplorasi pertanaman cabai Jawa Timur, yaitu isolat E1, E3C2 dan F2B1 (Tabel 1). Isolat $P$. capsici juga merupakan isolat koleksi hasil eksplorasi pertanaman cabai Jawa Timur dengan kode Cb6, berasal dari Desa Tegalgondo, Kecamatan Dau, Kabupaten Malang, Jawa Timur.

\section{Perlakuan Benih}

Biopriming dan priming sebagai perlakuan benih mengacu pada metode Ibrahim et al. (2014) dan Syamsuddin (2010). Benih cabai sebelum perlakuan terlebih dahulu diberi disinfektan dengan merendam benih dalam alkohol $70 \%$ selama 3 menit. Benih dicuci tiga kali dengan akuades yang telah disterilkan dalam autoklaf pada suhu $121{ }^{\circ} \mathrm{C}$ dengan tekanan $1.02 \mathrm{MPa}$ selama 15 menit, kemudian dikering-anginkan dalam laminar air flow cabinet (LAFC) selama 1 jam. Sebanyak 450 benih yang telah dikeringkan, diberi perlakuan dengan cara direndam dalam $50 \mathrm{~mL}$ suspensi isolat rizobakteri selama 24 jam pada suhu $20{ }^{\circ} \mathrm{C}$. Benih yang telah direndam, kemudian ditiriskan dan dikeringanginkan dalam LAFC selama 1 jam sebelum disemai (Ibrahim et al., 2014).

Suspensi isolat rizobakteri dibuat dengan menambahkan $10 \mathrm{~mL}$ akuades steril ke dalam cawan petri berisi media potato dextrose agar (PDA) dan isolat rizobakteri (umur 3-4 hari setelah inokulasi). Sebanyak 1
$\mathrm{mL}$ suspensi tersebut ditambahkan ke dalam $50 \mathrm{~mL}$ potato dextrose broth (PDB) kemudian dicampur menggunakan shaker dengan kecepatan 100 rpm selama 48 jam (Syamsuddin, 2010). Suspensi isolat rizobakteri dihitung kerapatan populasinya, menggunakan spektrofotometer pada $\mathrm{OD}_{600}$. Suspensi kombinasi isolat rizobakteri dibuat dengan mencampurkan 2-3 suspensi isolat rizobakteri, masing-masing perbandingan $1: 1 \mathrm{v} / \mathrm{v}$.

Priming benih cabai menggunakan larutan metalaksil konsentrasi $800 \mathrm{ppm}$ (Rosadiah et al., 2015). Larutan metalaksil dibuat dengan cara mengencerkan $0.04 \mathrm{~g}$ metalaksil (Saromil, 35\% metalaksil) dalam 50 $\mathrm{mL}$ akuades. Benih cabai yang telah diberi desinfektan, kemudian direndam dalam larutan metalaksil selama 24 jam pada suhu $20{ }^{\circ} \mathrm{C}$. Benih yang telah direndam, kemudian ditiriskan dan dikering-anginkan dalam LAFC selama 1 jam sebelum disemai.

\section{Rancangan Percobaan}

Percobaan disusun menggunakan rancangan acak kelompok satu faktor, yang mana biopriming dengan rizobakteri sebagai faktor perlakuan. Perlakuan benih biopriming dan priming terdiri atas 11 taraf sebagai berikut:

1. R0- : kontrol negatif (benih direndam dalam PDB tanpa rizobakteri dan tanpa inokulasi $P$. capsici)

2. R0+ : kontrol positif (benih direndam dalam PDB tanpa rizobakteri dan diinokulasi $P$. capsici)

3. R0RA : kontrol benih direndam dalam air 24 jam (suhu $20{ }^{\circ} \mathrm{C}$ ) 
4. R0TR : kontrol benih tanpa rendam

5. R0M : Priming dengan metalaksil $(50 \mathrm{~mL}$, konsentrasi $800 \mathrm{ppm}$ )

6. R1 : Biopriming dengan isolat rizobakteri 1

7. R2 : Biopriming dengan isolat rizobakteri 2

8. R3 : Biopriming dengan isolat rizobakteri 3

9. R4 : Biopriming dengan kombinasi isolat rizobakteri 1 dan 2

10.R5 : Biopriming dengan kombinasi isolat rizobakteri 1 dan 3

11.R6 : Biopriming dengan kombinasi isolat rizobakteri 1, 2, dan 3

Masing-masing perlakuan diulang empat kali, sehingga terdapat 44 satuan percobaan.

\section{Penyemaian Benih Cabai}

Benih yang telah diberi perlakuan disemai dalam seed tray, dengan media pembibitan berupa campuran tanah, pasir, arang sekam, cocopit (1:1:1:1 v/v/v/v). Persemaian cabai dalam rumah kaca dan pemeliharaan dilakukan secara kontinu. Setiap unit percobaan terdiri atas 100 benih, sehingga terdapat 4400 satuan pengamatan.

Variabel pengamatan fase pengecambahan (pembibitan) meliputi daya berkecambah (DB), potensi tumbuh maksimum (PTM), kecepatan tumbuh $\left(\mathrm{K}_{\mathrm{CT}}\right)$, indeks vigor (IV), keserempakan tumbuh $\left(\mathrm{K}_{\mathrm{ST}}\right)$, tinggi bibit dan jumlah daun.

\section{Penanaman dan pertumbuhan tanaman cabai}

Benih yang telah disemai (45 hari setelah tanam) dipilih secara acak untuk dipindah-tanam bersamaan dengan media semainya, ke dalam polibag (satu bibit per polibag) dengan media tanam berupa tanah, pupuk kandang, dan arang sekam steril (2:1:1 $\mathrm{v} / \mathrm{v} / \mathrm{v})$. Masing-masing satuan percobaan terdiri atas 15 tanaman, sehingga terdapat 660 satuan pengamatan. Pemeliharaan tanaman cabai secara kontinu meliputi penyiraman, penyiangan, pemupukan pertama $(3.4 \mathrm{~g}$ per 3 $\mathrm{kg}$ media tanam, 7 hari setelah pindah tanam) dan pemupukan kedua ( $2.4 \mathrm{~g}$ per $3 \mathrm{~kg}$ media tanam, 21 hari setelah pindah tanam) menggunakan pupuk NPK majemuk 15:15:15, pengendalian hama (penyemprotan insektisida apabila memang benar-benar diperlukan), dan pemangkasan daun wiwilan (tunas air).

\section{Pembuatan dan Inokulasi Tanah Inokulum Phytophthora capsici}

Tanah inokulum $P$. capsici ditambahkan ke dalam media tanam cabai berumur 4 minggu setelah pindah tanam. Penambahan tanah inokulum dilakukan dengan cara menyebar $10 \mathrm{~g}$ tanah inokulum di sekeliling pangkal batang (tanpa pelukaan) pada setiap polibag kecuali kontrol negatif. Tanah inokulum dibuat berdasarkan metode Manohara (1988) dengan cara $2 \mathrm{~kg}$ tanah (kering dan diayak) ditambah 1 $\mathrm{kg}$ pasir (kering dan diayak), kemudian dicampur dengan $4 \%$ oatmeal (halus), dan diberi air secukupnya ( $\pm 15 \mathrm{~mL}$ per $50 \mathrm{~g}$ campuran tanah, pasir dan oatmeal). Selanjutnya, tanah inokulum distrerilisasi sebanyak dua kali dengan autoklaf pada suhu $120{ }^{\circ} \mathrm{C}$ selama 20 menit (jeda waktu sterilisasi pertama dan kedua adalah 24 jam). Potongan biakan $P$. capsici umur 5 hari setelah inokulasi diinvestasikan ke tanah yang sudah steril dan diinkubasi pada suhu ruang $\left(23-25{ }^{\circ} \mathrm{C}\right)$ selama 2 minggu.

Variabel pengamatan setelah pindah tanam (fase pertumbuhan tanaman) meliputi kejadian penyakit (Babadoost et al., 2008), tinggi tanaman, jumlah daun, dan diameter batang.

Analisis data menggunakan uji $\mathrm{F}$, dan apabila terjadi pengaruh nyata dilanjutkan dengan uji DMRT pada taraf 5\%. Data variabel kejadian penyakit juga diuji Kontras Ortogonal pada taraf 5\%.

\section{HASIL DAN PEMBAHASAN}

\section{Kondisi Umum Lokasi Percobaan}

Percobaan dilakukan dalam rumah kaca Kebun Percobaan Leuwikopo, Kecamatan Dramaga, Kabupaten Bogor dengan ketinggian 240 meter di atas permukaan laut (m dpl). Rumah kaca memiliki jendela yang terbuat dari kawat sehingga tidak tertutup rapat. Suhu siang hari di dalam rumah kaca berkisar antara 28-33 ${ }^{0} \mathrm{C}$. Paranet dengan kerapatan sekitar $40 \%$ dipasang di sekeliling jendela rumah kaca, untuk mengurangi serangan hama. Hama yang sering dijumpai selama percobaan berlangsung antara lain ulat (Spodoptera litura), kutu daun (Myzus persicae), kutu putih (Bemisia tabaci), dan trip (Thrips sp.). Pengendalian hama dengan cara menyemprotkan insektisida, bahan aktif Abamektin dan Karbosulfan secara bergantian. 
Tabel 2. Pengaruh biopriming benih terhadap daya berkecambah (DB), potensi tumbuh maksimum (PTM), kecepatan tumbuh $\left(\mathrm{K}_{\mathrm{CT}}\right)$, indeks vigor (IV), dan keserempakan tumbuh $\left(\mathrm{K}_{\mathrm{ST}}\right)$

\begin{tabular}{llllll}
\hline Perlakuan & $\mathrm{DB}(\%)$ & $\mathrm{PTM}(\%)$ & $\begin{array}{c}\mathrm{K}_{\mathrm{CT}}(\% \text { etmal } \\
1)\end{array}$ & $\mathrm{IV}(\%)$ & $\mathrm{K}_{\mathrm{ST}}(\%)$ \\
\hline R0 & $66.5 \mathrm{a}$ & $67.5 \mathrm{a}$ & $8.2 \mathrm{a}$ & $32.0 \mathrm{a}$ & $49.5 \mathrm{a}$ \\
$\mathrm{R} 1$ & $39.3 \mathrm{dc}$ & $39.8 \mathrm{~cd}$ & $4.5 \mathrm{bc}$ & $12.3 \mathrm{bc}$ & $26.8 \mathrm{bcd}$ \\
$\mathrm{R} 2$ & $40.3 \mathrm{bcd}$ & $42.8 \mathrm{bcd}$ & $4.6 \mathrm{bc}$ & $15.5 \mathrm{~b}$ & $27.3 \mathrm{bcd}$ \\
$\mathrm{R} 3$ & $59.8 \mathrm{ab}$ & $60.8 \mathrm{ab}$ & $7.6 \mathrm{a}$ & $29.5 \mathrm{a}$ & $49.5 \mathrm{a}$ \\
$\mathrm{R} 4$ & $55.5 \mathrm{abc}$ & $56.8 \mathrm{abc}$ & $6.4 \mathrm{ab}$ & $19.3 \mathrm{ab}$ & $38.5 \mathrm{abc}$ \\
$\mathrm{R} 5$ & $31.3 \mathrm{~d}$ & $32.8 \mathrm{~d}$ & $3.4 \mathrm{c}$ & $6.5 \mathrm{~cd}$ & $22.3 \mathrm{~cd}$ \\
R6 & $30.3 \mathrm{~d}$ & $30.5 \mathrm{~d}$ & $3.5 \mathrm{c}$ & $11.3 \mathrm{bc}$ & $21.0 \mathrm{~cd}$ \\
R0RA & $58.5 \mathrm{ab}$ & $59.3 \mathrm{ab}$ & $7.8 \mathrm{a}$ & $33.3 \mathrm{a}$ & $45.8 \mathrm{ab}$ \\
R0TR & $58.0 \mathrm{ab}$ & $60.3 \mathrm{ab}$ & $5.9 \mathrm{ab}$ & $6.8 \mathrm{~cd}$ & $31.0 \mathrm{abcd}$ \\
$\mathrm{R} 0 \mathrm{M}$ & $49.5 \mathrm{abc}$ & $50.3 \mathrm{abc}$ & $4.5 \mathrm{bc}$ & $2.8 \mathrm{~d}$ & $16.3 \mathrm{~d}$ \\
\hline KK & 12.5 & 12.2 & 12.8 & 21.9 & 20.0 \\
\hline Keterangan: & Angka pada kolom yang sama dengan huruf yang sama tidak berbeda nyata berdasarkan DMRT pada \\
& taraf $\alpha=5 \%$. R0 (kontrol, benih direndam dalam PDB tanpa perlakuan rizobakteri), R1 (perlakuan \\
& benih dengan isolat E1), R2 (isolat E3C2), R3 (isolat F2B1), R4 (kombinasi isolat E1+E3C2), R5 \\
& (kombinasi isolat E1+F2B1), R6 (kombinasi isolat E1+E3C2+F2B1), R0RA (benih direndam dalam air \\
& 24 jam), R0TR (benih tanpa rendam), R0M (benih direndam dalam metalaksil). Sebelum diolah data \\
& ditransformasikan dengan rumus $\sqrt{x}+5$ &
\end{tabular}

\section{Evaluasi Biopriming dengan Rizobakteri terhadap Pertumbuhan Tanaman Cabai dan Kejadian Penyakit Busuk Phytophthora}

Pengaruh biopriming dengan rizobakteri terhadap viabilitas dan vigor benih dapat dilihat dalam Tabel 2. Berdasarkan hasil penelitian diketahui bahwa biopriming benih R3 (isolat F2B1) memiliki nilai yang relatif tinggi baik pada variabel daya berkecambah (DB), potensi tumbuh maksimum (PTM), kecepatan tumbuh $\left(\mathrm{K}_{\mathrm{CT}}\right)$, indeks vigor (IV), dan keserempakan tumbuh $\left(\mathrm{K}_{\mathrm{ST}}\right)$, meskipun tidak berbeda nyata bila dibandingkan dengan kontrol tanpa rizobakteri (R0) maupun perlakuan benih dengan merendam dalam air (R0RA).

Perlakuan R3 (isolat F2B1) nyata memiliki kemampuan untuk meningkatkan pertumbuhan kecambah, meskipun nilai tersebut belum menunjukkan pencapaian maksimal. Hal ini kemungkinan disebabkan oleh penyesuaian rizobakteri yang menempel pada permukaan benih (atau bahkan terserap dalam benih) selama proses biopriming berlangsung dan setelah ditanam pada media semai. Aktivitas bakteri dalam beradaptasi inilah yang diduga menyebabkan pengaruh terhadap hasil dari setiap variabel pengamatan.

Kontrol perlakuan benih tanpa rendam (R0TR) pada Tabel 2 ditujukan untuk mengoreksi hasil pengujian $\mathrm{DB}$, IV, dan $\mathrm{K}_{\mathrm{CT}}$ benih sebelum perlakuan. Hasil tersebut menunjukkan bahwa viabilitas dan vigor benih rendah, bahkan di bawah standar benih bermutu (standar pemerintah yang tercantum dalam kemasan 75-80\%). Menurut Siri et al. (2013), perkecambahan benih paprika melebihi $90 \%$ tidak memerlukan restorasi (invigorasi), sedangkan perkecambahan benih lebih rendah dari $80 \%$ tidak dapat dikembalikan lebih besar dari $80 \%$. Berdasarkan nilai $\mathrm{K}_{\mathrm{CT}}$, IV, $\mathrm{K}_{\mathrm{ST}}$ pada kontrol perlakuan benih rendam dalam air (R0RA), kontrol perlakuan-priming dalam media PDB tanpa rizobakteri (R0), dan biopriming dengan isolat F2B1 (R3) (Tabel 2), membuktikan bahwa perlakuan priming nyata meningkatkan vigor benih dibandingkan kontrol benih tanpa rendam (R0TR). Perlakuan biopriming memiliki nilai $\mathrm{K}_{\mathrm{CT}}$, IV, dan $\mathrm{K}_{\mathrm{ST}}$ lebih rendah dibanding dengan kontrol (baik R0 maupun R0RA), diduga disebabkan oleh perbedaan potensial larutan priming. Larutan priming berupa media PDB yang telah ditambah dengan rizobakteri kemungkinan memiliki potensial larutan yang lebih rendah (larutan lebih pekat) dibandingkan air dan media PDB tanpa rizobakteri. Benih yang digunakan dalam perlakuan memiliki kadar air sebesar $5.5 \%$, sehingga untuk mencapai kesetimbangan antara potensial air dalam benih dengan potensial larutan priming membutuhkan waktu yang relatif lama. Menurut Jeller et al. (2003), semakin rendah nilai potensial air dalam 
benih, waktu yang dibutuhkan dalam proses osmoconditioning semakin lama. Disamping itu, adanya aktivitas rizobakteri menyesuaikan diri pada lingkungan baru diduga berpengaruh terhadap viabilitas dan vigor benih. Berdasarkan hasil ini, dapat disimpulkan bahwa media PDB sebagai larutan priming dan media hidup bagi rizobakteri, tidak menghambat perkecambahan benih.

Daya berkecambah (DB) perlakuan biopriming dengan rizobakteri secara umum lebih rendah dibanding dengan kontrol tanpa rizobakteri (R0), kontrol rendam dalam air (R0RA) maupun kontrol tanpa rendam (R0TR). Hal tersebut diduga disebabkan oleh viabilitas benih rendah sebelum perlakuan (sebesar 58\% pada perlakuan tanpa rendam/ R0TR). Menurut Zaghdani (2002), viabilitas benih rendah dapat disebabkan oleh kerusakan mekanis berupa retakan pada testa selama penyimpanan, sehingga menyebabkan kebocoran benih. Kebocoran benih menyebabkan kerusakan benih selama proses imbibisi. Proses imbibisi yang terlalu cepat dan tidak terkontrol atau disebut imbibition damagel imbibition injury, didukung oleh kadar air benih rendah sebesar $5.5 \%$, sehingga beda potensial air dalam benih dengan larutan priming terlalu besar. Hal ini ditunjukkan oleh nilai DB yang tidak berbeda nyata dengan nilai potensi tumbuh maksimum (PTM). Ward dan Powell (1983) menyatakan bahwa benih dengan kelembaban rendah sangat rentan terhadap stres selama penyerapan air.

Imbibisi merupakan periode awal benih menyerap air yang ditentukan oleh mutu benih. Zaghdani (2002) menjelaskan bahwa imbibisi air berfungsi sebagai aktivitas enzimatik dan transportasi reaktan. Banyak air yang diserap benih tergantung pada komposisi benih, jenis benih, kadar air benih sebelum imbibisi, kondisi kulit benih, serta faktor dari luar benih seperti suhu dan status air.

Biopriming dengan kombinasi isolat E1 dan F2B1 (R5) menunjukkan hasil terbaik pada variabel tinggi bibit dan jumlah daun selama di persemaian (Tabel 3 dan Tabel 4). Peran rizobakteri terbukti mempengaruhi pertumbuhan bibit di persemaian. Benih dapat tumbuh dalam kondisi optimal, memanfaatkan nutrisi dari media persemaian dan air yang diberikan secara maksimal, mengingat selama pemeliharaan tanaman belum diberikan pupuk tambahan. Hal ini seperti yang dijelaskan oleh Mendes et al. (2013), bahwa rizobakteri memiliki kemampuan sebagai biofertilizer, menstimulasi pertumbuhan akar, mengontrol stres abiotik, dan mengendalikan penyakit.

Tabel 3. Pengaruh biopriming benih terhadap tinggi bibit 21-42 hari setelah tanam (HST) di persemaian

\begin{tabular}{llllc}
\hline \multirow{2}{*}{ Perlakuan } & \multicolumn{4}{c}{ Tinggi Bibit $(\mathrm{cm})$} \\
\cline { 2 - 5 } & $21 \mathrm{HST}$ & $28 \mathrm{HST}$ & $35 \mathrm{HST}$ & $42 \mathrm{HST}$ \\
\hline R0 & $4.37 \mathrm{~cd}$ & $6.25 \mathrm{bc}$ & $8.42 \mathrm{bcd}$ & $12.12 \mathrm{bc}$ \\
R1 & $4.74 \mathrm{bcd}$ & $6.28 \mathrm{bc}$ & $8.28 \mathrm{bcd}$ & $10.01 \mathrm{~cd}$ \\
R2 & $4.14 \mathrm{~d}$ & $5.96 \mathrm{c}$ & $6.92 \mathrm{~d}$ & $8.64 \mathrm{~d}$ \\
R3 & $4.89 \mathrm{bc}$ & $6.99 \mathrm{~b}$ & $9.86 \mathrm{~b}$ & $13.05 \mathrm{ab}$ \\
R4 & $4.74 \mathrm{bcd}$ & $6.61 \mathrm{bc}$ & $8.41 \mathrm{bcd}$ & $11.39 \mathrm{bcd}$ \\
R5 & $5.63 \mathrm{a}$ & $8.17 \mathrm{a}$ & $11.75 \mathrm{a}$ & $15.12 \mathrm{a}$ \\
R6 & $5.23 \mathrm{ab}$ & $6.23 \mathrm{bc}$ & $7.85 \mathrm{~cd}$ & $9.90 \mathrm{~cd}$ \\
R0RA & $4.42 \mathrm{~cd}$ & $5.85 \mathrm{c}$ & $7.47 \mathrm{~cd}$ & $9.17 \mathrm{~d}$ \\
R0TR & $4.48 \mathrm{~cd}$ & $6.40 \mathrm{bc}$ & $8.91 \mathrm{bc}$ & $12.25 \mathrm{bc}$ \\
R0M & $4.15 \mathrm{~d}$ & $6.01 \mathrm{c}$ & $7.26 \mathrm{~cd}$ & $9.19 \mathrm{~d}$ \\
\hline KK & 7.9 & 9.0 & 12.8 & 15.2 \\
\hline
\end{tabular}

Keterangan: Angka pada kolom yang sama dengan huruf yang sama tidak berbeda nyata berdasarkan DMRT pada taraf $\alpha=5 \%$. R0 (kontrol, benih direndam dalam PDB tanpa perlakuan rizobakteri), R1 (biopriming benih dengan isolat E1), R2 (isolat E3C2), R3 (isolat F2B1), R4 (kombinasi isolat E1+E3C2), R5 (kombinasi isolat $\mathrm{E} 1+\mathrm{F} 2 \mathrm{~B} 1$ ), R6 (kombinasi isolat $\mathrm{E} 1+\mathrm{E} 3 \mathrm{C} 2+\mathrm{F} 2 \mathrm{~B} 1$ ), R0RA (benih direndam dalam air 24 jam), R0TR (benih tanpa rendam), R0M (benih direndam dalam metalaksil). 
Tabel 4. Pengaruh biopriming benih terhadap jumlah daun 21-42 hari setelah tanam (HST) di persemaian

\begin{tabular}{lcccc}
\hline \multirow{2}{*}{ Perlakuan } & \multicolumn{5}{c}{ Jumlah Daun (helai) } \\
\cline { 2 - 5 } R0 & $21 \mathrm{HST}$ & $28 \mathrm{HST}$ & $35 \mathrm{HST}$ & $42 \mathrm{HST}$ \\
R1 & 2.0 & $3.0 \mathrm{bc}$ & $4.2 \mathrm{bc}$ & $5.6 \mathrm{bc}$ \\
R2 & 2.0 & $3.2 \mathrm{bc}$ & $4.0 \mathrm{c}$ & $5.0 \mathrm{bc}$ \\
R3 & 2.1 & $2.9 \mathrm{bc}$ & $3.7 \mathrm{c}$ & $4.8 \mathrm{bc}$ \\
R4 & 2.0 & $3.3 \mathrm{~b}$ & $4.8 \mathrm{~b}$ & $6.0 \mathrm{~b}$ \\
R5 & 2.2 & $2.9 \mathrm{bc}$ & $4.3 \mathrm{bc}$ & $5.3 \mathrm{bc}$ \\
R6 & 2.0 & $4.2 \mathrm{a}$ & $5.5 \mathrm{a}$ & $6.9 \mathrm{a}$ \\
R0RA & 2.0 & $3.0 \mathrm{bc}$ & $3.9 \mathrm{c}$ & $5.3 \mathrm{bc}$ \\
R0TR & $2.2 \mathrm{bc}$ & $4.0 \mathrm{c}$ & $4.9 \mathrm{bc}$ \\
R0M & 2.0 & $2.9 \mathrm{bc}$ & $4.2 \mathrm{bc}$ & $5.5 \mathrm{bc}$ \\
\hline KK & 2.1 & $2.8 \mathrm{c}$ & $3.8 \mathrm{c}$ & $4.7 \mathrm{c}$ \\
\hline
\end{tabular}

Keterangan: Angka pada kolom yang sama dengan huruf yang sama tidak berbeda nyata berdasarkan DMRT pada taraf $\alpha=5 \%$. R0 (kontrol, benih direndam dalam PDB tanpa perlakuan rizobakteri), R1 (biopriming benih dengan isolat E1), R2 (isolat E3C2), R3 (isolat F2B1), R4 (kombinasi isolat E1+E3C2), R5 (kombinasi isolat $\mathrm{E} 1+\mathrm{F} 2 \mathrm{~B} 1$ ), R6 (kombinasi isolat $\mathrm{E} 1+\mathrm{E} 3 \mathrm{C} 2+\mathrm{F} 2 \mathrm{~B} 1)$, R0RA (benih direndam dalam air 24 jam), R0TR (benih tanpa rendam), R0M (benih direndam dalam metalaksil).

Biopriming R5 (isolat E1+F2B1) berpengaruh nyata terhadap tinggi bibit dan jumlah daun 28-42 HST (Tabel 3 dan Tabel 4). Hal ini ditunjukkan oleh selisih tinggi bibit seluruh kontrol dan perlakuan pada 21 HST berkisar antara 0.01-0.4 cm, sedangkan selisih tinggi bibit pada 42 HST sebesar $0.5-2 \mathrm{~cm}$. Menurut Amrullah (2000), kandungan klorofil daun berpengaruh positif terhadap komponen pertumbuhan seperti jumlah daun, tinggi tanaman, dan jumlah cabang. Disamping itu, pertumbuhan tanaman sangat bergantung pada dominasi apikal. Faktor yang mempengaruhi dominasi apikal adalah hormon, transport air dan nutrisi dari tanah, fotosintesis dan alokasi hasil asimilasi.

Pertumbuhan tanaman cabai setelah pindah tanam menunjukkan peningkatan yang nyata. Pada variabel tinggi tanaman, kombinasi isolat E1 dan F2B1 (perlakuan R5) menunjukkan nilai yang relatif tinggi meskipun tidak berbeda nyata dengan kontrol positif dan kontrol negatif (Tabel 5). Biopriming benih tidak berpengaruh nyata terhadap variabel jumlah daun (Tabel 6). Biopriming benih berpengaruh nyata terhadap diameter batang, dan perlakuan rizobakteri (R1-R6) tidak berbeda nyata (Tabel 7).

Tabel 5. Pengaruh biopriming benih terhadap tinggi tanaman 7-35 hari setelah pindah tanam (HSP) di polibag

\begin{tabular}{llllll}
\hline \multirow{2}{*}{ Perlakuan } & \multicolumn{5}{c}{ Tinggi Tanaman $(\mathrm{cm})$} \\
\cline { 2 - 6 } & $7 \mathrm{HSP}$ & $14 \mathrm{HSP}$ & $21 \mathrm{HSP}$ & $28 \mathrm{HSP}$ & $35 \mathrm{HSP}$ \\
\hline R0+ & $16.17 \mathrm{a}$ & $19.82 \mathrm{a}$ & $25.14 \mathrm{a}$ & $33.90 \mathrm{ab}$ & $44.81 \mathrm{ab}$ \\
R0- & $14.73 \mathrm{abc}$ & $19.06 \mathrm{ab}$ & $25.40 \mathrm{a}$ & $36.02 \mathrm{a}$ & $49.22 \mathrm{a}$ \\
R1 & $12.14 \mathrm{bc}$ & $16.07 \mathrm{abc}$ & $22.07 \mathrm{ab}$ & $31.39 \mathrm{ab}$ & $45.16 \mathrm{ab}$ \\
R2 & $11.28 \mathrm{c}$ & $14.86 \mathrm{bc}$ & $20.56 \mathrm{ab}$ & $30.07 \mathrm{ab}$ & $43.82 \mathrm{ab}$ \\
R3 & $13.96 \mathrm{abc}$ & $17.10 \mathrm{abc}$ & $21.47 \mathrm{ab}$ & $29.92 \mathrm{ab}$ & $40.39 \mathrm{ab}$ \\
R4 & $13.60 \mathrm{abc}$ & $17.23 \mathrm{abc}$ & $21.75 \mathrm{ab}$ & $29.70 \mathrm{ab}$ & $40.67 \mathrm{ab}$ \\
R5 & $15.84 \mathrm{ab}$ & $19.30 \mathrm{a}$ & $25.01 \mathrm{a}$ & $34.03 \mathrm{ab}$ & $44.62 \mathrm{ab}$ \\
R6 & $11.97 \mathrm{c}$ & $15.83 \mathrm{abc}$ & $22.27 \mathrm{ab}$ & $31.60 \mathrm{ab}$ & $43.72 \mathrm{ab}$ \\
R0RA & $12.19 \mathrm{bc}$ & $15.72 \mathrm{abc}$ & $20.33 \mathrm{ab}$ & $27.46 \mathrm{~b}$ & $36.73 \mathrm{~b}$ \\
R0TR & $14.42 \mathrm{abc}$ & $18.43 \mathrm{ab}$ & $23.98 \mathrm{ab}$ & $32.06 \mathrm{ab}$ & $42.40 \mathrm{ab}$ \\
R0M & $10.97 \mathrm{c}$ & $14.13 \mathrm{c}$ & $19.27 \mathrm{~b}$ & $27.50 \mathrm{~b}$ & $38.04 \mathrm{~b}$ \\
\hline KK & 17.2 & 14.9 & 14.3 & 14.8 & 15.3 \\
\hline
\end{tabular}

Keterangan: Angka pada kolom yang sama dengan huruf yang sama tidak berbeda nyata berdasarkan DMRT pada taraf $\alpha=$ 5\%. R0+ (kontrol positif, benih direndam dalam PDB tanpa perlakuan rizobakteri dengan inokulasi P. capsici), R0(kontrol negatif, benih direndam dalam PDB tanpa perlakuan rizobakteri dan tanpa inokulasi $P$. capsici), R1 (biopriming benih dengan isolat E1), R2 (isolat E3C2), R3 (isolat F2B1), R4 (kombinasi isolat E1+E3C2), R5 (kombinasi isolat $\mathrm{E} 1+\mathrm{F} 2 \mathrm{~B} 1$ ), R6 (kombinasi isolat $\mathrm{E} 1+\mathrm{E} 3 \mathrm{C} 2+\mathrm{F} 2 \mathrm{~B} 1$ ), R0RA (benih direndam dalam air 24 jam), R0TR (benih tanpa rendam), R0M (benih direndam dalam metalaksil). Tanah inokulum $P$. capsici diberikan pada 28 hari setelah pindah tanam di sekitar pangkal batang tanaman cabai dibawah permukaan tanah. 
Tabel 6. Pengaruh biopriming benih terhadap jumlah daun 7-35 hari setelah pindah tanam (HSP) di polibag

\begin{tabular}{lccccc}
\hline \multirow{2}{*}{ Perlakuan } & \multicolumn{5}{c}{ Jumlah Daun (helai) } \\
\cline { 2 - 6 } & 7 HSP & 14 HSP & 21 HSP & 28 HSP & 35 HSP \\
\hline R0+ & 9.4 & 12.6 & 15.5 & 23.3 & 41.0 \\
R0- & 8.6 & 11.7 & 15.5 & 24.8 & 42.4 \\
R1 & 8.2 & 12.5 & 14.6 & 22.6 & 40.8 \\
R2 & 8.3 & 11.9 & 14.6 & 23.5 & 39.4 \\
R3 & 8.1 & 10.3 & 13.3 & 20.2 & 34.5 \\
R4 & 7.4 & 11.6 & 14.2 & 22.0 & 35.1 \\
R5 & 9.0 & 11.7 & 15.1 & 23.2 & 39.0 \\
R6 & 9.7 & 13.0 & 15.7 & 23.8 & 38.7 \\
R0RA & 8.2 & 11.1 & 14.2 & 20.5 & 32.0 \\
R0TR & 8.9 & 12.0 & 14.4 & 23.2 & 38.1 \\
R0M & 9.2 & 10.5 & 13.6 & 20.0 & 32.2 \\
\hline KK & 7.8 & 7.6 & 5.6 & 8.4 & 12.1 \\
\hline Kete
\end{tabular}

Keterangan: Angka pada kolom yang sama dengan huruf yang sama tidak berbeda nyata berdasarkan DMRT pada taraf $\alpha$ $=5 \%$. R0+ (kontrol positif, benih direndam dalam PDB tanpa perlakuan rizobakteri dengan inokulasi $P$. capsici), R0- (kontrol negatif, benih direndam dalam PDB tanpa perlakuan rizobakteri dan tanpa inokulasi $P$. capsici), R1 (biopriming benih dengan isolat E1), R2 (isolat E3C2), R3 (isolat F2B1), R4 (kombinasi isolat $\mathrm{E} 1+\mathrm{E} 3 \mathrm{C} 2$ ), $\mathrm{R} 5$ (kombinasi isolat $\mathrm{E} 1+\mathrm{F} 2 \mathrm{~B} 1$ ), $\mathrm{R} 6$ (kombinasi isolat $\mathrm{E} 1+\mathrm{E} 3 \mathrm{C} 2+\mathrm{F} 2 \mathrm{~B} 1$ ), R0RA (benih direndam dalam air 24 jam), R0TR (benih tanpa rendam), R0M (benih direndam dalam metalaksil). Tanah inokulum $P$. capsici diberikan pada 28 hari setelah pindah tanam di sekitar pangkal batang tanaman cabai dibawah permukaan tanah. Sebelum diolah data ditransformasikan dengan rumus $\sqrt{x}+5$.

Pertumbuhan tanaman diduga tidak hanya dipengaruhi oleh faktor dari dalam benih (dalam hal ini termasuk biopriming benih dengan rizobakteri), tetapi juga terdapat pengaruh dari luar benih/ lingkungan. Lingkungan pertumbuhan tanaman erat kaitannya dengan ketersediaan hara dalam media tanam, kebutuhan air, cahaya serta penambahan nutrisi melalui pemupukan dalam jumlah yang sama. Hal tersebut menyebabkan pertumbuhan cabai tidak menunjukkan banyak perbedaan.

Karakteristik rizobakteri sebagai PGPR ditunjukkan dengan kemampuannya dalam sintesis fitohormon terutama IAA, siderofor, dan ACC deaminase yang akan memicu kegiatan enzim tertentu. Selain itu beberapa Bacillus spp. memiliki kemampuan sebagai bakteri pelarut fosfat sehingga meningkatkan penyerapan hara melalui akar tanaman (Rajkumar et al., 2005; Lee et al., 2008). Fitohormon 1-aminocyclopropane-1-carboxylate deaminase, disingkat ACC deaminase, mampu meningkatkan pertumbuhan dan daya tahan tanaman terhadap cekaman lingkungan ekstrim serta serangan patogen (Glick et al., 2007). Menurut Mendes et al. (2013), koloni bakteri berperan penting dalam melepaskan kation dari mineral tanah yang diperlukan tidak hanya untuk bakteri sendiri melainkan juga nutrisi bagi tanaman.

Hasil penelitian Syamsuddin (2010), perlakuan benih dengan rizobakteri Bacillus spp., Pseudomonas spp., dan Serratia spp. nyata meningkatkan jumlah daun cabai pada 6 MSP. Ibrahim et al. (2014) menyatakan bahwa perlakuan benih dengan rizobakteri isolat ST116B meningkatkan jumlah daun. Menurut Rosadiah et al. (2015), perlakuan benih dengan isolat ST116B, CM8 maupun kombinasi keduanya mampu meningkatkan jumlah daun tanaman cabai. Hasil tersebut berbeda dengan hasil penelitian ini, perlakuan biopriming tidak berpengaruh nyata terhadap jumlah daun. Biopriming dengan rizobakteri nyata mempengaruhi tinggi tanaman dan diameter batang cabai. Hal ini diduga akibat akumulasi fitohormon IAA yang dihasilkan oleh rizobakteri maupun dari tanaman itu sendiri, banyak terkonsentrasi pada pertumbuhan tanaman, terutama perpanjangan sel batang.

Perlakuan biopriming dengan isolat E1+F2B1 (perlakuan R5) menunjukkan persentase kejadian penyakit busuk Phytophthora relatif lebih rendah $6.1 \%$ dibanding kontrol positif (R0+) sebesar 13.3\%, 5 HSI tanah inokulum P. capsici (Tabel 8). 
Tabel 7. Pengaruh biopriming benih terhadap diameter batang 7-35 hari setelah pindah tanam (HSP) di polibag

\begin{tabular}{lccccc}
\hline \multirow{2}{*}{ Perlakuan } & \multicolumn{5}{c}{ Diameter Batang $(\mathrm{mm})$} \\
\cline { 2 - 6 } & $7 \mathrm{HSP}$ & $14 \mathrm{HSP}$ & $21 \mathrm{HSP}$ & $28 \mathrm{HSP}$ & $35 \mathrm{HSP}$ \\
\hline R0+ & 2.0 & $2.5 \mathrm{ab}$ & 3.0 & $3.9 \mathrm{ab}$ & $4.0 \mathrm{~b}$ \\
R0- & 2.0 & $2.6 \mathrm{a}$ & 3.1 & $4.3 \mathrm{a}$ & $4.7 \mathrm{a}$ \\
R1 & 2.0 & $2.4 \mathrm{ab}$ & 3.0 & $3.9 \mathrm{ab}$ & $4.4 \mathrm{ab}$ \\
R2 & 2.0 & $2.3 \mathrm{~b}$ & 3.0 & $3.9 \mathrm{ab}$ & $4.1 \mathrm{~b}$ \\
R3 & 2.0 & $2.3 \mathrm{ab}$ & 2.9 & $3.7 \mathrm{ab}$ & $4.0 \mathrm{~b}$ \\
R4 & 2.0 & $2.4 \mathrm{ab}$ & 3.1 & $3.8 \mathrm{ab}$ & $4.1 \mathrm{~b}$ \\
R5 & 2.0 & $2.5 \mathrm{ab}$ & 3.0 & $3.8 \mathrm{ab}$ & $4.0 \mathrm{~b}$ \\
R6 & 2.0 & $2.4 \mathrm{ab}$ & 3.1 & $3.9 \mathrm{ab}$ & $4.2 \mathrm{ab}$ \\
R0RA & 2.0 & $2.4 \mathrm{ab}$ & 2.8 & $3.5 \mathrm{~b}$ & $3.8 \mathrm{~b}$ \\
R0TR & 2.0 & $2.4 \mathrm{ab}$ & 3.1 & $3.5 \mathrm{~b}$ & $4.0 \mathrm{~b}$ \\
R0M & 2.0 & $2.2 \mathrm{~b}$ & 2.8 & $3.7 \mathrm{ab}$ & $4.1 \mathrm{ab}$ \\
\hline KK & 1.0 & 6.8 & 10.1 & 10.1 & 8.4 \\
\hline
\end{tabular}

Keterangan: Angka pada kolom yang sama dengan huruf yang sama tidak berbeda nyata berdasarkan DMRT pada taraf $\alpha=5 \%$. R0 + (kontrol positif, benih direndam dalam PDB tanpa perlakuan rizobakteri dengan inokulasi P. capsici), R0- (kontrol negatif, benih direndam dalam PDB tanpa perlakuan rizobakteri dan tanpa inokulasi $P$. capsici), R1 (biopriming benih dengan isolat E1), R2 (isolat E3C2), R3 (isolat $\mathrm{F} 2 \mathrm{~B} 1$ ), R4 (kombinasi isolat $\mathrm{E} 1+\mathrm{E} 3 \mathrm{C} 2$ ), R5 (kombinasi isolat $\mathrm{E} 1+\mathrm{F} 2 \mathrm{~B} 1$ ), R6 (kombinasi isolat $\mathrm{E} 1+\mathrm{E} 3 \mathrm{C} 2+\mathrm{F} 2 \mathrm{~B} 1$ ), R0RA (benih direndam dalam air 24 jam), R0TR (benih tanpa rendam), R0M (benih direndam dalam metalaksil). Tanah inokulum $\quad$ P. capsici diberikan pada 28 hari setelah pindah tanam di sekitar pangkal batang tanaman cabai dibawah permukaan tanah.

Tabel 8. Pengaruh biopriming benih terhadap kejadian penyakit busuk Phytophthora 5-20 hari setelah inokulasi (HSI)*

\begin{tabular}{lcrrrrr}
\hline \multirow{2}{*}{ Perlakuan } & \multicolumn{7}{c}{ Kejadian Penyakit (\%) } \\
\cline { 2 - 7 } & $5 \mathrm{HSI}$ & $8 \mathrm{HSI}$ & $11 \mathrm{HSI}$ & $14 \mathrm{HSI}$ & $17 \mathrm{HSI}$ & $20 \mathrm{HSI}$ \\
\hline R0+ & $13.3 \mathrm{ab}$ & $13.3 \mathrm{~b}$ & $29.4 \mathrm{ab}$ & $37.2 \mathrm{a}$ & $44.4 \mathrm{a}$ & $45.6 \mathrm{a}$ \\
R0- & $0.0 \mathrm{~d}$ & $0.0 \mathrm{c}$ & $0.0 \mathrm{c}$ & $0.0 \mathrm{~b}$ & $0.0 \mathrm{~b}$ & $0.0 \mathrm{~b}$ \\
R1 & $20.0 \mathrm{a}$ & $22.8 \mathrm{a}$ & $46.1 \mathrm{a}$ & $46.1 \mathrm{a}$ & $48.3 \mathrm{a}$ & $50.6 \mathrm{a}$ \\
R2 & $11.1 \mathrm{bc}$ & $15.6 \mathrm{ab}$ & $27.8 \mathrm{ab}$ & $30.0 \mathrm{a}$ & $39.4 \mathrm{a}$ & $40.6 \mathrm{a}$ \\
R3 & $15.0 \mathrm{ab}$ & $18.9 \mathrm{ab}$ & $27.2 \mathrm{ab}$ & $35.6 \mathrm{a}$ & $42.8 \mathrm{a}$ & $43.9 \mathrm{a}$ \\
R4 & $12.2 \mathrm{ab}$ & $14.4 \mathrm{ab}$ & $28.3 \mathrm{ab}$ & $35.0 \mathrm{a}$ & $42.2 \mathrm{a}$ & $42.2 \mathrm{a}$ \\
R5 & $6.1 \mathrm{c}$ & $13.3 \mathrm{~b}$ & $22.8 \mathrm{~b}$ & $30.0 \mathrm{a}$ & $37.2 \mathrm{a}$ & $37.8 \mathrm{a}$ \\
R6 & $13.9 \mathrm{ab}$ & $17.2 \mathrm{ab}$ & $27.2 \mathrm{~b}$ & $34.4 \mathrm{a}$ & $40.6 \mathrm{a}$ & $41.1 \mathrm{a}$ \\
R0RA & $15.0 \mathrm{ab}$ & $17.2 \mathrm{ab}$ & $37.8 \mathrm{ab}$ & $37.8 \mathrm{a}$ & $45.0 \mathrm{a}$ & $46.1 \mathrm{a}$ \\
R0TR & $17.8 \mathrm{ab}$ & $25.0 \mathrm{a}$ & $33.9 \mathrm{ab}$ & $38.9 \mathrm{a}$ & $43.3 \mathrm{a}$ & $44.4 \mathrm{a}$ \\
R0M & $17.8 \mathrm{ab}$ & $21.1 \mathrm{ab}$ & $35.0 \mathrm{ab}$ & $41.1 \mathrm{a}$ & $45.6 \mathrm{a}$ & $46.1 \mathrm{a}$ \\
\hline KK & 17.7 & 13.7 & 10.9 & 11.0 & 8.0 & 8.1 \\
\hline
\end{tabular}

Keterangan: Angka pada kolom yang sama dengan huruf yang sama tidak berbeda nyata berdasarkan DMRT pada taraf $\alpha=5 \%$. R0+ (kontrol positif, benih direndam dalam PDB tanpa perlakuan rizobakteri dengan inokulasi $P$. capsici), R0- (kontrol negatif, benih direndam dalam PDB tanpa perlakuan rizobakteri dan tanpa inokulasi $P$. capsici), R1 (biopriming benih dengan isolat E1), R2 (isolat E3C2), R3 (isolat $\mathrm{F} 2 \mathrm{~B} 1$ ), R4 (kombinasi isolat $\mathrm{E} 1+\mathrm{E} 3 \mathrm{C} 2$ ), R5 (kombinasi isolat E1+F2B1), R6 (kombinasi isolat $\mathrm{E} 1+\mathrm{E} 3 \mathrm{C} 2+\mathrm{F} 2 \mathrm{~B} 1$ ), R0RA (benih direndam dalam air 24 jam), R0TR (benih tanpa rendam), R0M (benih direndam dalam metalaksil). Tanah inokulum $P$. capsici diberikan pada 28 hari setelah pindah tanam di sekitar pangkal batang tanaman cabai dibawah permukaan tanah. *33-48 hari setelah pindah tanam (HSP). Sebelum diolah data ditransformasikan dengan rumus $\ln (x+1)$.

Mahartha et al. (2013) menyatakan rizobakteri yang berasal dari rizosfer memiliki mekanisme resistensi alami serta mampu memberikan perlindungan terhadap tanaman dari serangan patogen. Rizobakteri sebagai biokontrol, dipilih berdasarkan kemampuannya sebagai antagonis langsung terhadap cendawan patogen, kemampuan adaptasi di lingkungan, dan induksi resistensi bagi tanaman inang (Aravind et al., 2008). Menurut Babalola 
(2010), strain biokontrol yang dapat melindungi tanaman inang dari patogen memiliki kemampuan kolonisasi yang kuat dan menghasilkan senyawa beracun bagi patogen seperti HCN, phenazine, pyrrolnitrin, pyoluteorin, dan 2.4-diacetylphloroglucinol (2.4-DAPG). Produksi HCN lebih banyak ditemukan pada Pseudomonas spp. (88.89\%) dibanding Bacillus spp. (50\%) (Ahmad et al., 2008). Hasil penelitian Gleeson et al. (2010) menyatakan bahwa 2.4-DAPG mengganggu fungsi mitokondria dalam Saccharomyces cereviseae.

Perlakuan priming dengan metalaksil tidak efektif mengendalikan penyakit busuk Phytophthora (Tabel 8). Semua perlakuan biopriming belum efektif mengendalikan penyakit busuk Phytophthora karena tidak berbeda nyata dengan kontrol positif, akan tetapi biopriming R5 menunjukkan persentase kejadian penyakit busuk Phytophthora nyata lebih rendah dibandingkan perlakuan priming dengan metalaksil (R0M), 5 HSI tanah inokulum $P$. capsici. Hasil uji kontras ortogonal menunjukkan biopriming R5 (kombinasi isolat $\mathrm{E} 1+\mathrm{F} 2 \mathrm{~B} 1$ ) umur 5 HSI tanah inokulum $P$. capsici lebih baik dibanding penggunaan metalaksil $(\mathrm{P}-$ value $=0.025)$, dan perlakuan biopriming lainnya $(\mathrm{P}-$ value $=$ 0.013). Hasil ini sesuai dengan penelitian Rosadiah et al. (2015) bahwa biopriming dengan rizobakteri menurunkan kejadian penyakit busuk Phytoptora lebih rendah (3$7 \%$ ) dibanding perlakuan metalaksil (10\%). Penggunaan fungisida metalaksil dan mefenoksam efektif mengendalikan penyakit busuk Phytophthora pada fase pembibitan, namun kurang efektif saat fase pertumbuhan di lapangan (Keinath, 2007). Menurut Syamsuddin (2010), rizobakteri memberikan hasil lebih baik dibanding fungisida metalaksil yang memiliki durasi singkat, karena rizobakteri mampu berperan sebagai biokontrol dan menginduksi ketahanan sistemik tanaman cabai lebih lama.

Efektivitas rizobakteri sebagai biokontrol terhadap $P$. capsici belum menunjukkan hasil yang maksimal pada 14-20 HSI. Hal ini diduga disebabkan oleh tiga faktor. Pertama, strain P. capsici yang diisolasi dari sentra produksi cabai di Jawa Timur relatif lebih virulen. Hal ini dibuktikan dari gejala busuk Phytophthora yang mulai tampak 4-5 HSI (Tabel 8). Pada penelitian sebelumnya dengan isolat $P$. capsici yang berbeda, gejala busuk Phytophthora baru terlihat dua minggu setelah inokulasi (Syamsuddin, 2010; Ibrahim et al., 2014; Rosadiah et al., 2015). Kedua, diduga jumlah tanah inokulum (10 g per polibag) yang diberikan pada tanaman cabai terlalu banyak. Jumlah inokulan $P$. capsici yang terlalu banyak tidak dapat diimbangi dengan jumlah rizobakteri yang diberikan saat perlakuan biopriming benih. Kontrol perlakuan priming dengan fungisida metalaksil juga tidak mampu mengendalikan inokulum $P$. capsici. Ketiga, kemungkinan populasi rizobakteri yang diaplikasikan terhadap benih, jumlahnya berkurang setelah berada di dalam rizosfer. Menurut Mendes et al. (2013), sebagian besar spesies rizobakteri memperoleh energi dari asimilasi senyawa organik, sehingga ketersediaan senyawa organik dan karbon yang terbatas dalam sebagian besar tanah, merupakan faktor pembatas yang paling umum untuk pertumbuhan bakteri tanah.

\section{KESIMPULAN}

Biopriming benih cabai dengan kombinasi isolat E1+F2B1 (kerapatan rizobakteri berturut-turut sebesar $1.06 \times 10^{9} c f u$ $\mathrm{mL}^{-1}$ dan $1.20 \times 10^{9}$ cfu $\mathrm{mL}^{-1}$ ), meningkatkan tinggi bibit dan jumlah daun umur 21-42 HST di persemaian. Biopriming benih cabai dengan isolat $\mathrm{F} 2 \mathrm{~B} 1$ atau kombinasi isolat $\mathrm{E} 1+\mathrm{F} 2 \mathrm{~B} 1$ meningkatkan tinggi tanaman pada umur 1421 HSP di rumah kaca. Biopriming benih cabai dengan kombinasi isolat $\mathrm{E} 1+\mathrm{F} 2 \mathrm{~B} 1$ menurunkan kejadian penyakit busuk Phytophthora dari $13.3 \%$ (kontrol positif) menjadi 6.1\%, 5 HSI tanah inokulum $P$. capsici. Perlakuan priming dengan metalaksil $800 \mathrm{ppm}$ tidak efektif mengendalikan penyakit busuk Phytophthora.

\section{UCAPAN TERIMA KASIH}

Ucapan terima kasih disampaikan kepada Kemenristekdikti melalui program Penelitian Strategi Nasional Tahun Anggaran 2015 atas dana penelitian yang telah diberikan, PT. East West atas benih varietas Laris, dan Balai Penelitian Tanaman Rempah dan Obat (Balittro) atas fasilitas yang telah disediakan, 
serta kepada semua pihak yang telah membantu dalam menyelesaikan penelitian ini.

\section{DAFTAR PUSTAKA}

Agarwal, V.K., J.B. Sinclair. 1997. Principle of Seed Pathology. Second edition. Boca Raton Florida (US): CRC Press Inc.

Ahmad, F., I. Ahmad, M.S. Khan. 2008. Screening of free-living rhizospheric bacteria for their multiple plant growth promoting activities. Microbiol Res. 163(2): 173-181.

Amrullah. 2000. Tingkat kandungan klorofil daun dan kontribusinya serta pengaruh pemupukan NPKMg dan pemberian metanol terhadap kandungan klorofil, pertumbuhan dan produktivitas tanaman cabai merah (Capsicum annuum L.) [Tesis]. Bogor (ID): Institut Pertanian Bogor.

Aravind, R., A. Kumar, S.J. Eapen, K.V. Ramana. 2008. Endophytic bacterial flora in root and stem tissues of black pepper (Piper nigrum L.) genotype: isolation, identification and evaluation against Phytophthora capsici. Applied Microbiology. 48: 58-64.

Babadoost, M., D. Tian, S.Z. Islam, C. Pavon. 2008. Challenges and options in managing Phytophthora blight (Phytophthora capsici) of cucurbits. Pitrat M, editor. Proceedings of the Ixth EUCARPIA Meeting on Genetics and Breeding of Cucurbitaceae. Avignon (FR): INRA.

Babalola, O.O. 2010. Beneficial bacteria of agricultural importance. Biotechnol Lett. 32: 1559-1570.

Gleeson, O., F. O'Gara, J.P. Morrissey. 2010. The Pseudomonas fluorescens secondary metabolite 2.4 diacetylphloroglucinol impairs mitochondrial function in Saccharomyces cerevisiae. Springer Science 97: 261-273.
Glick, B.R., B. Todorovic, J. Czarny, Z. Cheng, J. Duan 2007. Promotion of plant growth by bacterial ACC deaminase. Crit. Rev. Plant Sci. 26: 227-242.

Hausbeck, M.K., K.H. Lamour. 2004. Phytophthora capsici on vegetable crops: research progress and management challenges. Plant Diseases. 88(12): 1292-1303.

Ibrahim, A., S. Ilyas, D. Manohara. 2014. Perlakuan benih cabai (Capsicum annuит L.) dengan rizobakteri untuk mengendalikan Phytophthora capsici, meningkatkan vigor benih dan pertumbuhan tanaman. Bul. Agrohorti. 2(1): 22-30.

Ilyas. S. 2012. Ilmu dan Teknologi Benih (Teori dan Hasil-hasil Penelitian). Bogor (ID): IPB press.

Ilyas. S., K.V. Asie, G.A.K. Sutariati, Sudarsono. 2015. Biomatriconditioning or biopriming with biofungicides or biological agents applied on hot pepper (Capsicum annuиm L.) seeds reduced seedborne Colletotrichum capsici and increased seed quality and yield. Acta Hortic. 1105: 89-96.

Ilyas, S, G.A.K. Sutariati, F.C. Suwarno, Sudarsono. 2002. Matriconditioning improved quality and protein level of medium vigor hot pepper seed. Seed Technol. 24: 65-75.

[ISTA] International Seed Testing Association. 2014. International Rules for Seed Testing. Basserdorf (CH): ISTA.

Jeller, H., S.C.J.G.A. Perez, J. Raizer. 2003. Water uptake, priming, drying and storage effects in Cassia excelsa Schrad seeds. Braz. J. Biol. 63(1): 61-68.

Keinath, A.P. 2007. Sensitivity of populations of phytophthora capsici from south carolina to mefenoxam, dimethomorph, zoxamide, and cymoxanil. Plant Disease. 91(6): 743-748. 
Lee, K.J., S. Kamala-Kannan, H.S. Sub, C.K. Seong, G.W. Lee. 2008. Biological control of Phytophthora blight in red pepper (Capsicum annuum L.) using Bacillus subtilis. World J. Microbiol Biotechnol. 24: 1139-1145.

Mahartha, K.A., K. Khalimi, G.N.A.S. Wirya. 2013. Uji efektivitas rizobakteri sebagai agen antagonis terhadap Fusarium oxysporum f. sp. capsici penyebab penyakit layu fusarium pada tanaman cabai rawit (Capsicum frutescens L.). eJ. Agro Tropika. 2(3): 145-154.

Manohara, D. 1988. Ekologi Phytophthora palmivora (Bulter), penyebab penyakit busuk pangkal batang lada (Piper nigrum L.) [Disertasi]. Institut Pertanian Bogor. Bogor.

Mendes, R., P. Garbeva, J.M. Raaijmakers. 2013. The rhizosphere microbiome: significance of plant beneficial, plant pathogenic, and human pathogenic microorganisms. FEMS Microbiol Rev. 37: 634-663.

Rajkumar, M., W.H. Lee, K.J. Lee. 2005. Screening of bacterial antagonists for biological control of Phytophthora blight of pepper. J. Basic Microbiol. 45(1): 55-63.

Rosadiah, N.F., S. Ilyas, D. Manohara. 2015. Perlakuan benih cabai (Capsicum апnиит L.) dengan rizobakteri secara tunggal atau kombinasi dapat mengendalikan Phytophthora capsici dan meningkatkan pertumbuhan tanaman. J. Hort. Indonesia. 6(1): 1-10.
Siri, B., K. Vichitphan, P. Kaewnaree, S. Vichitphan, P. Klanrit. 2013. Improvement of quality, membrane integrity and antioxidant systems in sweet pepper (Capsicum annuиm Linn.) seeds affected by osmopriming. AJCS. 7(13): 2068-2073.

Sutariati, G.A.K., L.O. Safuan, A. Khaeruni, F. Handayani. 2014. Uji efektivitas teknik biopriming dan sumber benih terhadap viabilitas dan vigor bibit kakao. Agriplus. 24(2): 111-122.

Syamsuddin. 2010. Perlakuan benih untuk pengendalian penyakit busuk Phytophthora, peningkatan hasil dan mutu benih cabai merah (Capsicum аппиитm L). [Disertasi]. Institut Pertanian Bogor. Bogor.

Wahyuno, D. 2009. Pengendalian terpadu busuk pangkal batang lada. Perspektif. 8(1): 17-29.

Ward, F.H., A.A. Powell. 1983. Evidence for repair processes in onion seeds during storage at high seed moisture contents. J. Expert. Bot. 34: 277-282.

Yunianti, R., S. Sastrosumarjo, S. Sujiprihati, M. Surahman, S.H. Hidayat. 2007. Ketahanan 22 genotipe cabai (Capsicum spp.) terhadap Phytophthora capsici Leonian dan keragaman genetiknya. Bul. Agron. 35(2): 103-111.

Zaghdani, A.S. 2002. Effect of pre-sowing seed treatments for quality of cucumber, pepper, tomato and pea seed [Disertation]. Hongaria (HU): Budapest Hungary. 